Analisis Kemampuan Berpikir.... (Anisa Amalia, Heni Pujiastuti)

\title{
ANALISIS KEMAMPUAN BERPIKIR TINGKAT TINGGI \\ PADA SISWA SMP YPWKS CILEGON DALAM MENYELESAIKAN SOAL POLA BILANGAN
}

\author{
Oleh: Anisa Amalia, Heni Pujiastuti \\ Email : anisamalia95@gmail.com \\ (Universitas Sultan Ageng Tirtayasa)
}

\begin{abstract}
Abstrak
Penelitian ini bertujuan untuk mengetahui apakah siswa sudah memiliki kemampuan berpikir tingkat tinggi dalam menyelesaikan soal pada materi pola bilangan. Berdasarkan tahapan taksonomi Bloom, keterampilan berpikir tingkat tinggi, yaitu keterampilan menganalisis (analyzing), mengevaluasi (evaluating), dan mencipta (creating) Jenis penelitian ini adalah penelitian deskriptif. Pengambilan data menggunakan metode tes dan wawancara. Berdasarkan hasil penelitian, kemampuan tingkat tinggi yang terdiri dari analisis tingkat kemampuan analisis siswa rata-rata mencapai 33,33\%, tingkat mengevaluasi mencapai 44,44\%, dan tingkat mencipta sebesar 0\% dari skor maksimal 100. Hasil wawancara menunjukkan bahwa kemampuan berpikir tingkat tinggi siswa sangat rendah karena mereka tidak terbiasa mengerjakan soal tes. Kemampuan berpikir tingkat tinggi memiliki kesinambungan antara satu dengan yang lainnya. Jika kemampuan analisis siswa rendah maka akan mempengaruhi kemampuan berpikir tingkat tinggi selanjutnya yaitu kemampuan mengevaluasi dan mencipta.
\end{abstract}

Kata Kunci : Kemampuan Berpikir Tingkat Tinggi, Taksonomi Bloom

\section{ANALYSIS OF HIGH ORDER THINKING SKILL IN YPWKS CILEGON MIDDLE SCHOOL STUDENTS IN COMPLETING THE PROBLEM OF NUMBERS}

\begin{abstract}
This study aims to determine whether students already have high-level thinking skills in solving problems on material number patterns. Based on Bloom's taxonomic stage, high-level thinking skills, namely the skills of analyzing, evaluating, and creating this type of research is descriptive research. Retrieval of data using test and interview methods. Based on the results of the study, a high level of ability consisting of an analysis of the level of analysis ability of students reached an average of $33.33 \%$, an evaluation rate reached $44.44 \%$, and a creation rate of $0 \%$ of a maximum score of 100 . Interview results showed that the level of thinking ability High students are very low because they are not accustomed to doing test questions. The ability to think at a higher level has continuity with one another. If the student's analytical skills are low, it will affect the ability to think at a higher level, namely the ability to evaluate and create.
\end{abstract}

Keywords: Higher-Order Thinking Skills, Bloom's Taxonomy. 


\section{A. PENDAHULUAN}

Kemampuan berpikir merupakan hal penting dalam keberhasilan belajar matematika. Siswa merupakan salah satu sumber daya manusia yang produktif sehingga kualitas pemikirannya harus ditingkatkan agar mampu bersaing dalam perkembangan zaman ini. Kemampuan berpikir yang harus dimiliki siswa salah satunya adalah kemampuan berpikir tingkat tinggi. Kemampuan berpikir tingkat tinggi berhubungan dengan kemampuan penalaran yang logis, sistematis, kritis, cermat, dan kreatif. Hal tersebut sesuai dengan tujuan pembelajaran matematika di sekolah yaitu melatih cara berpikir siswa dalam menarik kesimpulan, mengembangkkan kemampuan memecahkan masalah, serta mengembangkan kemampuan untuk mengkomunikasikan ide-ide secara lisan, tulisan, dan sebagainya.

Kemampuan berpikir tingkat tinggi adalah proses berpikir kompleks dimana siswa mampu menguraikan materi, membuat kesimpulan, membangun representasi, menganalisis, dan membangun hubungan dengan melibatkan aktivitas mental yang paling dasar. Proses berpikir terdapat tingkatan dari rendah sampai tinggi. Hal ini dijabarkan dalam Taksonomi Bloom (Resnick, 1987).

Taksonomi Bloom merupakan struktur hierarki yang menjelaskan kemampuan berpikir seseorang mulai dari tingkat yang rendah hingga yang tinggi. Agar sesuai dengan kemajuan zaman, pada tahun 1994 Lorin Anderson Krathwohl memperbaiki taksonomi Bloom. Keterampilan dibagi menjadi dua bagian. Pertama, keterampilan tingkat rendah merupakan keterampilan berpikir paling mendasar yaitu mengingat (remembering), memahami (understanding), dan menerapkan (applying). Kedua adalah keterampilan berpikir tingkat tinggi, yaitu keterampilan menganalisis (analyzing), mengevaluasi (evaluating), dan mencipta (creating), taksonomi Bloom yang diperbaiki ini diberi nama Taksonomi Bloom Revisi (Anderson, 2001).

Berpikir tingkat tinggi juga dapat diartikan sebagai berpikir pada tingkat yang lebih tinggi, sehingga siswa tidak hanya mengingat, memahami dan menerapkan suatu fakta atau informasi yang diterima melainkan mampu menganalisis dan mengevaluasi fakta atau informasi hingga pada akhirnya siswa 
mampu menyerap informasi yang didapat dan merangkai pemahaman di dalam pikirannya sehingga siswa mampu menyampaikan informasi yang didapat menggunakan kata-katanya sendiri berdasarkan pemahamannya.

Siswa yang diberikan masalah-masalah matematika yang berorientasi pada HOTS (proses berpikir tingkat tinggi), dapat meningkatkan kemampuan berpikir siswa tersebut. Apabila siswa pada awalnya memiliki keterampilan berpikir remembering atau sedikit understanding karena masih bergantung pada rumus dan konsep sederhana maka dengan memberikan masalah-masalah matematika yang berorientasi HOTS, siswa diharapkan mampu memiliki keterampilan berpikir hingga creating (Wicasari, 2016).

Ciri-ciri soal tipe HOTS adalah soal yang menggunakan penalaran dan logika untuk mengambil keputusan, memprediksi, dan merefleksi, serta kemampuan menyusun strategi untuk memecahkan masalah kontekstual yang tidak rutin. Kemampuan yang sangat penting untuk menyelesaikan soal-soal HOTS yaitu emampuan menginterpretasi, mencari hubungan antar konsep, dan kemampuan mentransfer konsep satu ke konsep lain, merupakan (Kemendikbud, 2017).

Penelitian ini fokus pada siswa kelas IX sebab menurut Jean Piaget, pada usia 11-15 tahun siwa sedang pada tahap ke empat yaitu Fase Operation. Pada tahap ini, siswa dapat memikirkan situasi hipotesis secara penuh dan proses berpikir mereka tak lagi tergantung pada hal-ha yang real. Siswa sudah dapat menggunakan pola "kemungkinan" sebab siswa berpikir semakin logis dan abstrak (Hergenhahn, 2010).

Penelitian terdahulu yang berkaitan dengan kemampuan berpikir siswa, diantaranya hasil penelitian yang dilakukan oleh Purbaningrum (2017) menunjukkan bahwa kemampuan berpikir tingkat tinggi siswa masih tergolong rendah. Selain itu, penelitian yang dilakukan oleh Irawati (2018) menunjukkan bahwa dari skor maksimal 100\%, kemampuan analisis siswa rata-rata mencapai $30 \%$, tingkat mengevaluasi mencapai $32 \%$, dan tingkat mencipta mencapai $23 \%$. Berdasarkan nilai presentase tersebut menunjukkan bahwa kemampuan menyelesaikan soal HOTS masih rendah. Sedangkan penelitian yang dilakukan 
oleh Nuragni (2018) menyatakan bahwa ketuntasan hasil belajar siswa masih $27.59 \%$, hal ini menunjukkan bahwa kemampuan siswa dalam menyelesaikan soal tipe HOTS masih rendah. Berdasarkan beberapa penelitian tersebut dapat disimpulkan bahwa kemampuan berpikir tingkat tinggi pada siswa SMP masih dalam kategori rendah.

Hasil penelitian tersebut mendorong peneliti untuk melakukan penelitian yang sama. Penelitian ini dilakukan dengan tujuan untuk menganalisis kemampuan berpikir tingkat tinggi pada siswa di Cilegon khususnya pada materi pola bilangan. Materi pola bilangan dipilih sebab dianggap sulit oleh siswa karena membutuhkan skill analisis yang cukup tinggi. Penelitian ini penting untuk dilakukan sebab dapat membantu menentukan langkah selanjutnya agar dapat meningkatkan hasil belajar siswa.

\section{B. METODOLOGI PENELITIAN}

Jenis penelitian yang dilakukan adalah penelitian deskriptif. Penelitian deskripif ini bertujuan agar memperoleh gambaran secara sistematis, faktual dan akurat mengenai fakta-fakta, sifat-sifat serta hubungan antar fenomena yang diselidiki. Pada hal ini, peneliti ingin mengetahui gambaran tentang hasil belajar siswa kelas IX SMP YPWKS Cilegon tahun ajaran 2019/2020 dalam menyelesaikan soal matematika tipe HOTS pada materi pokok Pola Bilangan.

Subjek penelitian adalah sebagian siswa kelas IX SMP YPWKS Cilegon tahun ajaran 2019/2020. Subjek ini dipilih berdasarkan tingkat kemampuan matematis tinggi, sedang dan rendah yang diinformasikan oleh guru bidang studi yang bersangkutan. Sedangkan objek penelitian ini adalah kemampuan menyelesaikan soal matematika tipe HOTS pada pokok bahasan Pola Bilangan di kalangan siswa kelas IX SMP YPWKS Cilegon tahun ajaran 2019/2020 ditinjau dari hasil belajar.

Instrumen yang digunakan adalah soal tes tertulis dan wawancara. Tes tertulis dilakukan sesuai dengan pokok bahasan yang diujikan. Tes ini berupa tes subjektif dimana tes ini berbentuk soal uraian (essay). Melalui tes ini, siswa dituntut untuk menjawab permasalahan yang diberikan secara terurai dan 
menjelaskan menggunakan bahasa tulisan yang jelas dan lengkap. Instrument ini digunakan untuk mengetahui hasil belajar siswa dan melihat kualitas respon siswa dalam menyelesaikan soal tipe HOTS. Sedangkan wawancara dilakukan untuk mengetahui pemahaman siswa mengenai materi yang diujikan, terutama yang berkaitan dengan soal yang dibuat. Berikut ini rincian langkah-langkah penelitiannya:

Langkah pertama adalah memberikan masalah-masalah tipe HOTS. Tujuan dari langkah ini yaitu untuk mengetahui sejauh mana tingkat kemampuan logika berpikir peserta didik. Langkah kedua yaitu meminta peserta didik untuk mengerjakan soal tersebut dengan kemampuan berpikirnya masing-masing. Peserta didik diberikan keebasan untuk menemukan solusi dengan bekal pengetahuan yang mereka miliki. Langkah ketiga adalah menganalisis hasil pekerjaan peserta didik. Analisis yang yang dilakukan adalah melihat lamgkahlangkah siswa dalam menyelesaikan masalah. Langkah terakhir pada penelitian ini yaitu melakukan wawancara kepada siswa untuk mengklarifikasi jawaban yang mereka tulis agar tidak timbul kesalahan dalam penafsiran.

\section{HASIL PENELITIAN DAN PEMBAHASAN}

Menilai hasil siswa dan Melihat hasil rata-rata kemampuan siswa untuk Setelah memberikan soal-soal tipe HOTS kepada beberapa siswa, peneliti melakukan analisis terhadap hasil pekerjaan siswa. Berikut indikator berpikir tingkat tinggi yang perlu diamati:

Tabel 1. Indikator Berpikir Tingkat Tinggi yang Diamati

\begin{tabular}{|c|c|c|}
\hline No. & $\begin{array}{c}\text { Kemampuan } \\
\text { Berpikir Tingkat } \\
\text { Tinggi }\end{array}$ & Indikator yang Diamati \\
\hline 1 & Menganalisis & $\begin{array}{l}\text { 1. Menganalisis informasi yang masuk dan } \\
\text { membagi-bagi atau menstrukturkan } \\
\text { informasi ke dalam bagian yang lebih kecil } \\
\text { untuk mengenali pola atau hubungannya } \\
\text { 2. Mengenali serta membedakan factor } \\
\text { penyebab dan akibat sebuah scenario yang } \\
\text { rumit }\end{array}$ \\
\hline
\end{tabular}


3. Mengidentifikasi/merumuskan pertanyaan

$2 \quad$ Mengevaluasi

1. Memberikan penilaian terhadap solusi, gagasan, dan metodologi dengan menggunkan criteria yang cocok atau standar yang ada untuk memastikan nilai efektivitas atau manfaatnya.

2. Membuat hipotesis, mengkritik dan melakukan pengujian.

3. Menrima atau menolak suatu pernyataan berdasarkan criteria yang telah di tetapakan.

$3 \quad$ Mencipta

1. Membuat generalisasi suatu idea tau cara pandang terhadap sesuatu

2. Merancang suatu cara untuk menyelesaikan masalah.

Berdasarkan hasil analisis pada jawaban siswa didapatkan informasi bahwa:

Tabel 2. Tingkat Kemampuan Berpikir Tingkat Tinggi Siswa

\begin{tabular}{llll}
\hline \multicolumn{1}{c}{ Level HOTS } & \multicolumn{1}{c}{ Siswa I } & \multicolumn{1}{c}{ Siswa II } & \multicolumn{1}{c}{ Siswa III } \\
\hline Menganalisis & $33,33 \%$ & $33,33 \%$ & $33,33 \%$ \\
Mengevaluasi & $33,33 \%$ & $33,33 \%$ & $66.67 \%$ \\
Mencipta & $0 \%$ & $0 \%$ & $0 \%$ \\
\hline
\end{tabular}

Berdasarkan Tabel 1, diketahui bahwa rata-rata kemampuan menganalisis siswa sebesar 33,33\%. Rata-rata kemampuan mengevaluasi siswa sebesar 44,44\% dan rata-rata kemampuan mencipta sebesar 0\% dari skor maksimal $100 \%$. Kemampuan berpikir siswa memiliki kesinambungan antar tingkat kemampuan sebab dalam menyelesaikan soal matematika yang berlevel tinggi siswa melalui tahapan manipulasi data, informasi, dan ide untuk memecah makna dan implikasi, mensintesis, menggeneralisasikan, menjelaskan, membuat kesimpulan sementara, sampai akhirnya membuat suatu kesimpulan.

Saat siswa menyelesaikan masalah maka didalamnya terdapat proses pengidentifikasian masalah, yang dilanjutkan dengan melakukan analisis 
hubungan pola-pola yang ada menjadi penentu kemampuan berpikir siswa selanjutnya. Sehingga apabila siswa tidak memiliki kemampuan menganalisis yang baik, maka siswa akan kesulitan untuk mengevaluasi dan mencipta (Kusumaningrum, 2012).

Berdasarkan hasil wawancara diperoleh informasi bahwa siswa tidak memiliki rasa antusias saat mengerjakan soal-soal tipe HOTS. Siswa mengeluhkan bahwa soal yang diberikan terlalu sulit. Oleh karena itu, siswa tidak dapat menjawab soal tipe HOTS dengan maksimal. Hal ini disebabkan karena siswa tidak terbiasa mengerjakan soal-soal tipe HOTS. Berdasarkan pemaparan di atas, maka dapat dilihat bahwa motivasi siswa tergolong rendah. Motivasi belajar siswa berbanding lurus dengan hasil belajar yang dicapai. Apabila siswa memiliki motivasi tinggi, maka hasil belajar juga tinggi. Maka kebalikannya, apabila motivasi belajar siswa rendah, maka hasil belajarnya rendah (Pujiastuti, 2020).

\section{SIMPULAN}

Berdasarkan hasil penelitian dan pembahasan maka dapat disimpulkan bahwa kemampuan berpikir tingkat tinggi terdiri dari 3 tingkatan yaitu menganalisis (analyze), mengevaluasi (evaluate), dan mencipta (create). Kemampuan tingkat tinggi yang terdiri dari tingkat kemampuan analisis siswa rata-rata mencapai $33,33 \%$, tingkat mengevaluasi mencapai $44,44 \%$, dan tingkat mencipta sebesar 0\% dari skor maksimal 100. Kemampuan berpikir tingkat tinggi sangat rendah. Hasil wawancara menunjukkan bahwa kemampuan berpikir tingkat tinggi siswa sangat rendah karena mereka tidak terbiasa mengerjakan soal tes. Kemampuan berpikir tingkat tinggi memiliki kesinambungan antara satu dengan yang lainnya. Jika kemampuan analisis siswa rendah maka akan mempengaruhi kemampuan berpikir tingkat tinggi selanjutnya yaitu kemampuan mengevaluasi dan mencipta. 


\section{DAFTAR PUSTAKA}

Anderson, L.W., dan Krathwohl, D.R. (2001). A Taxonomy for Learning, Teaching, and Assesing: A Revision of Bloom's Taxonomy of Educatioanl Objectives. New York: Addison Wesley Longman, Inc.

Hergenhahn, B. R., \& Olson, M. H. (2010). Theories of Learning (Teori Belajar). Jakarta: Kencana.

Irawati, T. N. (2018). Abalisis Kemampuan Berfikir Tingkat Tinggi Siswa SMP Dalam Menyelesaikan Soal Pemecahan Masalah Matematika Pada Materi Bilangan Bulat. Jurnal Gammath, 03, 1-7.

Kemendikbud. (2017). Modul Penyusunan Soal Higher Order Thinking Skill (HOTS). Dirjen Pendidikan Dasar dan Menengah.

Kusumaningrum, M., \& Saefudin, A. A. (2012). Mengoptimalkan Kemampuan Berpikir Matematika melalui Pemecahan Masalah Matematika. Prosiding Kontribusi Pendidikan Matematika Dan Matematika Dalam Membangun Karakter Guru Dan Siswa, November, 978-979.

Nuragni, W. T. (2018). Analisis Kemampuan Siswa dalam Menyelesaikan Soal MatematikaTipe High Order Thinking pada Pokok Bahasan Pola Bilangan di Kalangan Siswa Kelas VIII E SMP Negeri 5 Yogyakarta Tahun Ajaran 2018/2019. Skripsi, Program Studi Pendidikan Matematika Universitas Sanata Dharma, Yogyakarta.

Pujiastuti, H. (2020). Analisis Kemampuan Pemecahan Masalah Ditinjau dari Motivasi Belajar Mtematika Siswa. Prima: Jurnal Pendidikan Matematika, $4(1), 1-10$.

Purbaningrum, K. A. (2017). Kemampuan Berpikir Tingkat Tinggi Siswa Smp Dalam Pemecahan Masalah Matematika Ditinjau Dari Gaya Belajar. Jurnal Penelitian Dan Pembelajaran Matematika, 10(2), 40-49.

Resnick, L. B. (1987). Education and Learning to Think. Washington, D.C: National Academy Press.

Wicasari, B., \& Ernaningsih, Z. (2016). Analisis Kemampuan Berpikir Siswa dalam Menyelesaikan Permasalahan Matematika yang Berorientasi pada HOTS. Prosiding Seminar Nasional Reforming Pedagogy, 249-254. 